\title{
Padrões de Desenvolvimento e de Oportunidade Social na América Latina e no Leste Asiático
}

\author{
Sedi Hirano e \\ Luis Estenssoro*
}

Resumo: Este artigo procura aprofundar a reflexão em torno dos padrões de desenvolvimento e de oportunidade social existentes no Leste Asíatico e na América Latina. Sustentamos aqui que a estrutura de poder mundial funda-se em modos de desenvolvimento diferenciados nas diversas regiões do planeta, que se reportam a diversos padrões de acumulação e inserção internacional das economias nacionais, empiricamente verificáveis em cada região geo-econômica. Partimos do pressuposto de que o modo de desenvolvimento anglo-americano produz estruturalmente mais pobreza e desigualdade social do que o modo de desenvolvimento japonês-asiático. Este regime de acumulação diferenciado permitiu ao conjunto de países capitaneados pelo Estado desenvolvimentista da Ásia construir um sistema de oportunidades sociais e econômicas que torna estas nações estruturalmente mais igualitárias, pois apresentam menores niveis de desigualdade social e pobreza.

Palavras-chave: Modos de Desenvolvimento, Sistema de Oportunidades Sociais, América Latina, Leste Asiático, Desigualdade Social.

Abstract: This article intends to deepen our knowledge about the development and social opportunity patterns present in East Asia and Latin America. We argue that the world power structure is based in different modes of development that exist in the planet's regions, which report themselves to different capital accumulation patterns and several enrollment ways of the national economies in the international economy. These patterns can be empirically verified in each geo-economic region. We admit that the British American mode of development produces structurally more poverty and more social inequality than the Japanese-Asian mode of development. This Asian countries' particular regime of accumulation allows the nations under the Asia's development state to offer an economic and social opportunities system that makes they structurally more equalitarian, with less social inequality and less poverty.

Keywords: Modes of Development, Social Opportunities System, Latin America, East Asia, Social Inequality.

* Sedi Hirano: Professor Doutor de Sociologia (FFLCH-USP) e Pró-Reitor de Cultura e Extensão da Universidade de São Paulo (USP), E-mail: sedhi@usp.br. Luis Estenssoro: Administrador Público (EAESP-FGV) e Doutor em Sociologia pela Universidade de São Paulo (USP). E-mail: luisestenssoro@hotmail.com. Recebido em 26/10/06 e aceito em 27/11/06. 


\section{Introdução}

Este artigo procura aprofundar a reflexão em torno dos padróes de desenvolvimento e de oportunidade social existentes no Leste Asiático e na América Latina, tema já abordado em trabalho anterior (HIRANO; ESTENSSORO, 2004). Trata-se de modalidades de desenvolvimento econômico-social que acontecem nas diversas regióes do planeta e que reúnem tipos semelhantes de formaçóes sociais em cada regiáo.

Sustentamos que a estrutura de poder mundial funda-se em modos de desenvolvimento diferenciados nas diversas regióes do planeta, que se reportam a padróes de acumulação e inserção internacional das economias nacionais, e que podem ser empiricamente verificados em cada região como sendo estruturalmente diferentes dos existentes nas outras regióes. Assim, podemos ter diversos modelos de crescimento econômico nacionais, isto é, modelos de política econômica e de políticas públicas, dentro de um conjunto de economias de uma região que têm, por sua vez, um padrão de acumulação diferenciado em relação a outras economias regionais existentes dentro do mesmo modo de produção capitalista hoje hegemônico.

Partimos do pressuposto de que o modo de desenvolvimento angloamericano produz estruturalmente mais pobreza e desigualdade do que o modo de desenvolvimento japonês-asiático. Compreendemos a América Latina como inserida no modo de desenvolvimento capitalista anglo-americano, pois o desenvolvimento capitalista dependente latino-americano está contido na esfera de influência inglesa e posteriormente norte-americana.

Johnson (1995) denomina o modo de desenvolvimento japonês-asiático de padrão "Meiji-Bismarckiano", onde o mercado é metodicamente orientado aos interesses sociais por um Estado desenvolvimentista. Desta forma, o mercado é utilizado para alcançar objetivos coletivos. Constitui-se então um capitalismo regulado, onde o Estado tem uma presença forte como planejador econômico. Trata-se de um "capitalismo social" ou de uma "economia mista" (TSURU, 1994), enquanto padrão de acumulação tecnologicamente sofisticado no qual o mercado é regulado em conformidade com as aspiraçóes dos grupos sociais que compóe a sociedade. De fato, nota-se uma ênfase no grupo e não no indivíduo, o que privilegia os laços de solidariedade comunitária dentro das fábricas, onde tomou forma o toyotismo, isto é, o relacionamento dentro 
de uma estrutura de poder descentralizada e com trabalho em equipe.

Amartya Sen (2000) afirma que o exemplo pioneiro de intensificação do desenvolvimento econômico "por meio da oportunidade social especificamente na área de educação básica, é obviamente o Japão". Segundo ele, este país, às vezes se esquece, "apresentava taxas de alfabetização mais elevadas do que a Europa mesmo na época da restauração Meiji, nas últimas décadas do século XIX”. Sen entende que o desenvolvimento econômico do Japão foi impulsionado pela progressão dos recursos humanos relacionada com as oportunidades sociais que foram geradas. "O denominado milagre do Leste Asiático, envolvendo outros países desta região, baseou-se em grande medida, em relaçóes causais semelhantes". E entre esses países estão a Coréia, a China, Taiwan e Cingapura (SEN, 2000).

Nesse sentido, a construção de um sistema de oportunidades sociais potencializa o desenvolvimento humano através do processo de expansão da educação, dos serviços de saúde e de outras condiçôes de vida humana. Para Sen (2000), provavelmente o resultado mais importante alcançado pelas economias do Leste Asiático, começando pelo Japão, foi ter solapado totalmente o preconceito tácito de que a montagem do sistema de oportunidades sociais seja realmente "um tipo de luxo que apenas os países ricos podem se dar".

As economias do Leste Asiático buscaram "comparativamente mais cedo a expansão em massa da educação e mais tarde, também dos serviços de saúde, e o fizeram, em muitos casos, antes de romper os grilhóes da pobreza generalizada. E colheram o que semearam” (SEN, 2000, p. 58). Nestes países, e particularmente na Coréia e no Japáo, houve crescimento econômico com distribuição de renda de maneira relativamente igualitária, o que "tem sido amplamente - e acertadamente - reconhecido" (SEN, 2000, p. 218). Há, no modo japonês-asiático de desenvolvimento capitalista, inquestionavelmente, um sistema planejado de ampliação das oportunidades sociais e, portanto, de alargamento da cidadania.

No modo de desenvolvimento anglo-americano, ao contrário, o mercado é primordial, tornando-se o espaço predominante das atividades econômicas, além de ser formalmente autônomo em relação às esferas social, política e cultural. Neste modo de desenvolvimento, que inclui o regime de acumulação dependente latino-americano, o Estado se distancia formalmente do mercado, 
cabendo-lhe apenas a planificação das políticas públicas. Não há no modo de desenvolvimento capitalista anglo-americano, aparentemente, uma espécie de "nacionalismo empresarial" como encontrado no capitalismo desenvolvimentista de Estado japonês-asiático, no qual se valoriza muito a empresa enquanto pátria e lar comunitário. Tal concepção, associada a uma produção de qualidade voltada para a exportação de manufaturados e com grande investimento em pesquisa e inovação tecnológica, torna-se altamente competitiva no mercado internacional. Foi este modo de desenvolvimento asiático o criador do toyotismo, que aparece para superar o fordismo do padráo anglo-americano de desenvolvimento. ${ }^{1}$ Como veremos, em decorrência destas características no desenvolvimento das relações econômicas, os resultados sociais mais igualitários são evidentes nas economias do Leste Asiático.

Crise sistêmica e modos de desenvolvimento

Entretanto, há indícios que denotam que a crise social relacionada com a pobreza e com a desigualdade, que assola o Terceiro Mundo, não se resume apenas aos padróes de inserção internacional, em particular à crise do padrão de acumulação dependente latino-americano, amplamente estudada (CARDOSO, FALETTO, 1969; CASANOVA, 2002; ESTENSSORO, 2003; FERNANDES, 1973; FURTADO, 1987; GONÇALVES, 1999; GUNDER-FRANK, 1971; HIRANO, 1998; IANNI, 1988; KOWARICK, 1985; MARINI, 1992 e2000; QUIJANO, 1998; REYNA, 1994; ROUQUIÉ, 1991; SALAMA, 1999; SALAMA, VALIER, 1997; TOMASSINI, 1984; TOURAINE, 1989). Na verdade, a crise do capitalismo, enquanto modo de produção dominante que não consegue sustentar adequadamente a populaçáo mundial, configura-se como uma questão sistêmica. Como tal, não pode ser resolvida apenas por políticas de estabilização e crescimento econômico das nações periféricas. $\mathrm{O}$ fato de, por exemplo, o fenômeno da concentração de renda e do aumento da desigualdade ocorrer também nos países desenvolvidos ${ }^{2}$ contribui para reforçar o argumento de que a crise econômica

\footnotetext{
${ }^{1}$ Sobre toyotismo e fordismo ler Antunes (1999, p. 29-60).

${ }^{2}$ Nos EUA, o índice de Gini, que mede a desigualdade na sociedade, aumentou 22,4\% entre 1968 e 1994. No mesmo período a renda média do quintil mais rico cresceu 44\%, enquanto que a renda média do quintil mais pobre cresceu somente 8\%. Outro estudo mostra que, entre 1967 e 1998, todos os quintis perderam participação na renda, exceto o quintil superior, que aumentou de 43,8\% para 49,2\% sua participação. Nesse mesmo período, no qual o índice de Gini aumenta de 0,399 (1967) para 0,456 (1998), os 5\% mais ricos aumentam sua participação na renda de 17,5\% para 21,4\%. As tendências da renda domiciliar dos períodos $1967-80$ e 1980-92 são opostas: no primeiro período, os 20\% mais pobres
} 
do capitalismo é um problema global.

Assim, além da crise do padrão de acumulação dependente latinoamericano, podemos visualizar uma crise econômica capitalista que atravessa a segunda metade do século XX, como resultado da queda das taxas de lucro que se começa a verificar nos anos 1960, e que se traduz nas taxas baixas de investimento, poupança e crescimento. Por exemplo, o indicador de crescimento do produto mundial por habitante, que era de $4 \%$ entre 1960 e 1973, caiu para 2,4\% entre 1973 e 1980, e 1,2\% entre 1980 e 1993 (CHESNAIS, 1998). Ou seja, além das crises financeiras cada vez mais freqüentes e das recessões que se verificaram em 1948-49, 1952-53, 1957 58, 1960-61, 1966-67, 1970-71, 1974-75, 1980-82 e 1990-94, agora há um agravante estrutural que evidencia a dificuldade que o capitalismo tem de se tornar um sistema que propicie condiçôes de vida aceitáveis para todos.

Pela Tabela 1 vemos que o novo padrão de acumulação sob hegemonia financeira, isto é, com os ganhos de produtividade sendo apropriados pelo capital financeiro, revela-se, nos EUA e Europa (no modo de desenvolvimento anglo-americano), como um regime com menor crescimento do PIB, emprego, produtividade e acumulação, apesar destas regióes estarem no topo da hierarquia econômica mundial e apesar do seu imenso desenvolvimento tecnológico.

Tabela 1 - Taxas médias anuais de crescimento dos EUA e UE (1960-1999)

País

\begin{tabular}{|c|c|c|c|}
\hline País & & $1960-1973$ & 1980-1999* \\
\hline \multirow{4}{*}{ Estados Unidos } & PIB & 3,9 & 2,5 \\
\hline & Emprego & 1,8 & 1,5 \\
\hline & Produtividade** & 2,6 & 0,9 \\
\hline & Acumulação & 4,5 & 2,9 \\
\hline \multirow{4}{*}{ União Européia } & PIB & 4,7 & 2,1 \\
\hline & Emprego & 0,3 & 0,3 \\
\hline & Produtividade** & 5,1 & 1,9 \\
\hline & Acumulação & 5,6 & 1,9 \\
\hline
\end{tabular}

FONTE: A partir de dados da OECD. "Economic Outlook" (MATTOSO, 1999)

* Dados estimados e projetados para 1998 e 1999;

** Ref. período 1979-1997.

ganham 7,5\% e os mais ricos perdem 9,7\%; no período seguinte a tendência se inverte, os mais pobres perdem 11,6\% e os 20\% mais ricos ganham 17,7\% (WEINBERG, 1996; WEINBERG, JONES JR., 2000). 
Porém, esta crise mundial do capitalismo globalizado repercute de maneira diferente nas diversas regióes do globo devido aos diferentes modos de desenvolvimento regionais. As disparidades que encontramos na tabela a seguir nos dão um indicativo das diversas faces da situação sócio-econômica no capitalismo internacional hoje. São exatamente estas diferenças que permitem que se fale de "capitalismos" regionais (modos de desenvolvimento) de acordo com os padróes de acumulação japonês-asiático e anglo-americano. Assim, excetuando-se o centro dinâmico da economia mundial (Estados Unidos), podemos verificar, por exemplo, que o tamanho das economias asiáticas é maior e tende a crescer mais rapidamente do que as economias latino-americanas. $\mathrm{O}$ destaque certamente é a China. No entanto, devido à sua grande população, esta não acompanha a performance do PIB per capita da Coréia e do Japão, que apresentam indicadores bem acima da média latino-americana.

Tabela 2 - Dados econômicos de países selecionados

\section{ECONOMIA}

\begin{tabular}{|c|c|c|c|c|c|c|c|c|c|}
\hline \multirow{2}{*}{\multicolumn{2}{|c|}{$\begin{array}{c}\text { Populaçáo } \\
\text { (milhóes de hab.) }\end{array}$}} & \multirow{2}{*}{\multicolumn{2}{|c|}{$\begin{array}{l}\text { PIB, PPP* } \\
\text { (bilhóes } \\
\text { US\$ intern. } \\
\text { correntes) }\end{array}$}} & \multirow{2}{*}{\multicolumn{3}{|c|}{$\begin{array}{l}\text { PIB per capita, PPP } \\
\text { US\$ internacionais } \\
\text { correntes }\end{array}$}} & \multicolumn{3}{|c|}{$\begin{array}{c}\text { Crescimento médio anual } \\
(\%)\end{array}$} \\
\hline & & & & & & & \multicolumn{2}{|c|}{$\begin{array}{c}\text { Produto } \\
\text { Interno Bruto } \\
\text { (PIB) }\end{array}$} & \multirow{2}{*}{$\begin{array}{c}\text { Investimento } \\
\text { interno bruto } \\
90-99\end{array}$} \\
\hline PAIIS & 2000 & 1980 & 2000 & 1980 & 2000 & $E U A=100$ & $80-90$ & $90-00$ & \\
\hline EUA & 281 & 2.879 & 9.612 & 12.673 & 34.100 & 100,00 & 3,5 & 3,5 & 7,0 \\
\hline China & 1.262 & 414 & 5.019 & 422 & 3.920 & 11,50 & 10,1 & 10,3 & 12,8 \\
\hline Japão & 127 & 1.161 & 3.394 & 9.944 & 26.755 & 78,49 & 4,1 & 1,3 & 1,1 \\
\hline Coréia & 47 & 116 & 822 & 3.037 & 17.380 & 50,97 & 8,9 & 5,7 & .. \\
\hline Brasil & 170 & 475 & 1.299 & 3.916 & 7.300 & 24,41 & 2,7 & 2,9 & 3,1 \\
\hline México & 97 & 286 & 883 & 4.241 & 8.790 & 25,78 & 1,1 & 3,1 & 3,9 \\
\hline Argentina & 37 & 180 & 458 & 6.428 & 12.050 & 35,34 & $-0,7$ & 4,3 & $10,9^{* *}$ \\
\hline
\end{tabular}

FONTE: Banco Mundial, 2000

* Dados expressos em termos de Paridade de Poder de Compra (PPC ou PPP em Inglês) ** Dados Até 1998

Como sabemos, a América Latina tem uma população pobre que vive com menos recursos do que a população do mesmo estrato de renda segundo uma média mundial, e uma elite regional que recebe mais do que a média dos $20 \%$ mais ricos no mundo, em termos proporcionais. No entanto, na União 
Européia e na América do Norte, os $20 \%$ mais ricos recebem muito mais devido ao tamanho do PIB naqueles países. A Ásia do Sul e Ásia Oriental são regióes mais igualitárias porém mais pobres do que a América Latina e do que a média mundial, enquanto que a Ásia do Sudeste e o Pacífico combinam maior eqüidade com menos pobreza.

Assim, a base econômica e social é diferenciada de acordo com a regiáo. Ou seja, parte-se de patamares diferentes na América Latina e na Ásia para enfrentar o mesmo tipo de problema internacional, a saber, as crises e transformaçóes econômicas da era da globalização. Desta forma, estamos falando de realidades sócio-econômicas díspares quando nos referimos, por exemplo, ao Brasil comparado com a China, apesar das suas características comuns enquanto naçóes em desenvolvimento.

\section{Padrões de inserção e desenvolvimento: América Latina}

Para Salama e Valier (1997), os padróes de inserção na economia mundial das regióes periféricas (basicamente, no caso latino-americano: a economia primário-exportadora e a industrialização por substituição de importações) foram os responsáveis pela distribuição de renda vertical que deu origem à dinamização do crescimento. Isto é, instaurou-se um regime de acumulação que harmonizava o perfil da distribuição de renda com o da produção: "uma distribuição de renda que favorecia as classes médias, excluindo ainda mais os de renda menor; uma produção dinamizada pela expansão do setor de bens de consumo duráveis destinados principalmente a essas classes médias [...] e às camadas superiores, bem como pela demanda induzida dirigida ao setor de bens de capital". Ou seja, trata-se de um regime de acumulaçáo excludente, onde a situação dos excluídos dos benefícios da acumulação agravou-se com a inflação, as crises econômicas e a expansão do domínio financeiro.

Mais ainda, conforme afirmam estes autores (SALAMA; VALIER, 1997, p. 123-128), na América Latina os sistemas de proteção social são, simultaneamente, economicamente ineficientes e socialmente injustos. Primeiro porque têm um grau de universalização muito fraco: muitas pessoas ficam de fora, principalmente os da economia informal. Segundo porque náo são sistemas uniformes: os benefícios são extremamente diferenciados de acordo com o grupo social ou a região. Esta realidade faz com que o 
discurso antiestatal do liberalismo, que se quer social, traduza-se em políticas sociais com as seguintes características: são políticas sociais orientadas aos "extremamente pobres", assistencialistas, privatizantes, descentralizadas, e com apelo à mobilização "solidária" da população. $\mathrm{O}$ resultado econômico é que, apesar de uma diminuição provisória do empobrecimento, ocorre uma consolidação e aprofundamento da desigualdade social, e nenhuma redução da pobreza absoluta (embora em alguns casos consiga-se uma diminuição da proporção de pobres sobre o total da população, o que pode ser creditado ao crescimento populacional).

$\mathrm{Na}$ verdade, a ineficácia do sistema de oportunidades sociais, na América Latina, deve-se em grande parte à gestão neoliberal da crise econômica, que gerou desemprego, exclusão social e mais desigualdade e pobreza. Para se ter uma idéia, o número de pobres saltou de 135,9 milhóes, em 1980, para 224 milhões, em 2004, e o número de indigentes de 62,4 milhóes para 98 milhóes, no mesmo período. A isto se soma o nível da desigualdade nos países latino-americanos, que tem se mantido quase imutável ou até piorado ao longo dos anos: na virada do século, o índice de Gini era de 0,542 na Argentina, 0,640 no Brasil e 0,539 no México; para 0,501, 0,627 e 0,536, respectivamente, dez anos antes (CEPAL, 2004).

Segundo Ianni (1988, p. 191, p. 200-201), as sociedades latinoamericanas são sociedades organizadas com base no capitalismo dependente, ou seja, as suas relaçóes com os países centrais estão determinadas pelos processos econômicos e políticos que operam no centro do sistema capitalista mundial. Depois do fracasso da hipótese do capitalismo nacional e da hipótese do capitalismo associado, as experiências latino-americanas confirmaram o modelo de capitalismo dependente, onde as perspectivas dos sistemas político-econômicos do capitalismo periférico estão determinadas pelo seu centro de irradiação, que são os EUA. Percebemos que, neste sistema, é a própria reprodução ampliada do capital em escala mundial que exige a apropriação privada do produto do trabalho dos trabalhadores, pois, ao se internacionalizarem o capital, a tecnologia, a força de trabalho e a divisão social do trabalho, internacionalizam-se também as "relações, processos e estruturas de dominação política e apropriação econômica”, aí compreendidas as relaçóes e contradições entre as classes. Cria-se, então, uma 
contradição entre sociedade nacional e economia dependente, da qual o poder político não consegue libertar-se, daí a instabilidade dos sistemas políticos na América Latina.

Para Ianni (1988, p. 26, p. 186), a análise da dependência estrutural tornase profícua a partir da obra de Paul Baran, que possibilita a incorporação da abordagem da dependência à linha clássica de interpretação do imperialismo, o que significa que "a análise da dependência corresponde ao aprofundamento da análise do imperialismo, visto da perspectiva do subordinado". Afinal, as relações imperialistas implicam na criação ou reformulação das relações internas nos países dependentes. Mais ainda, as determinações imperialistas podem provocar rearranjos institucionais na sociedade e no Estado dos países subdesenvolvidos. A proposta teórico-metodológica de Ianni é manter a linha clássica de análise do imperialismo, enquanto processo político-econômico, mas incorporando-lhe as análises do colonialismo interno, existente nas áreas metropolitanas, e da dependência estrutural, existente na periferia do capitalismo.

Neste sentido, Ianni combina os conceitos de mais-valia e de excedente econômico ao analisar as estruturas de dominação política e apropriação econômica do imperialismo norte-americano na América Latina. São relações "carregadas de ambigüidade, controvérsia e contradições”, nas quais as classes dominantes (burguesia hegemônica e burguesia subalterna) disputam a apropriação do excedente econômico. Entretanto, "quando se passa a considerar os interesses das classes assalariadas, a disputa ocorre em torno da apropriação do lucro, ou mais-valia”. Assim, a dependência estrutural conceito que corresponde à "modificação e mesmo reversão de perspectiva relativamente à abordagem clássica das relaçóes do tipo imperialista” - diz respeito à exportação de excedente econômico efetivo e à exportação de maisvalia também.

$\mathrm{Na}$ verdade, a dependência estrutural atinge, além das estruturas de poder e estruturas de apropriação econômica, também as instituições e relações de comunicação, tecnológicas, educacionais, militares, culturais e religiosas. $\mathrm{Ou}$ seja, a influência é tal que o processo de desenvolvimento se vê condicionado nos seus principais aspectos. Neste contexto, "a dependência estrutural corresponde à manifestação concreta, no interior da sociedade subordinada, 
das relaçóes políticas e econômicas de tipo imperialista" (IANNI, 1988, p. 199-200). Ianni avança na análise e chega à conclusão que: 1) a dependência estrutural não se circunscreve ao âmbito econômico, mas pode ser notada também nas relaçóes e instituiçóes políticas; e que 2) a reformulação das relaçóes e estruturas de dependência não é um problema econômico, mas um problema político. O poder político é o elemento essencial da dependência estrutural, pois esta surge nas relaçóes econômicas externas, mas só se consolida e desenvolve quando adquire configuração política.

Florestan Fernandes (1973) analisa o atual padrão de dominação externa na América Latina como herdeiro do sistema colonial, do neocolonialismo e do imperialismo (padrôes anteriores). Recentemente, o padrão de dominação seria fruto da expansão das grandes empresas corporativas na região, representando o capitalismo monopolista. Trata-se de um "imperialismo total" que exerce um controle externo como no sistema colonial, mas com as condiçóes do moderno mercado capitalista, da tecnologia avançada e com a dominação externa compartilhada por diversas naçóes. Segundo Fernandes, o traço específico do imperialismo total consiste no fato de que ele organiza a dominação externa a partir de dentro e em todos os níveis da ordem social. Característica que "prova que uma economia satélite ou dependente não possui as condições estruturais e dinâmicas para sobrepujar nacionalmente, pelos esforços da burguesia, o subdesenvolvimento e suas conseqüências”.

Está então descartada a ilusão de uma revolução industrial liderada pela burguesia nacional, e está também consolidado o quadro de dominação externa que transforma as naçóes em fontes de excedente econômico e acumulação de capital para as naçóes capitalistas avançadas. Mesmo porquê, na explicação sociológica do subdesenvolvimento econômico de Florestan Fernandes (LIMOEIRO-CARDOSO, 1997), que se baseia no sistema de classes sociais e no modo como estas agem para fortalecer ou extinguir o regime social de produção econômica, o capitalismo dependente latino-americano implica relaçóes de dominação que conjugam a dominação externa com a dominação interna. Isto é, a acumulação de capital institucionaliza-se para promover a expansão concomitante dos núcleos hegemônicos interno e externo. Se a economia capitalista dependente não consegue monopolizar a apropriação do seu excedente econômico, significa que os assalariados e os destituídos 
são submetidos a mecanismos de sobre-apropriação e sobre-expropriação capitalistas. Trata-se de um padrão de acumulação de capital cuja forma Fernandes designa como "sobre-apropriação repartida do excedente econômico". Assim, a situação é redefinida pela ação recíproca de fatores estruturais, dinâmicos, externos e internos: "Os setores sociais que possuem o controle das sociedades latino-americanas são tão interessados e responsáveis por essa situação quanto os grupos externos, que dela tiram proveito. Dependência e subdesenvolvimento são um bom negócio para os dois lados" (FERNANDES, 1973, p. 26).

Desta forma, Fernandes nega a explicação do subdesenvolvimento enquanto atraso e a proposta decorrente: superação do subdesenvolvimento por meio da aceleração do crescimento econômico. Uma vez que Fernandes nega a possibilidade de superação dos desafios do desenvolvimento pelo capitalismo privado, uma alternativa para esta situação da América Latina seria em torno de um "novo tipo de capitalismo de Estado" ou então a "rebelião popular e radical de orientação socialista". A revolução seria a alternativa histórica para o capitalismo dependente, da mesma forma que o capitalismo de Estado pode representar uma alternativa para o desenvolvimento da regiáo.

Para Marini (2000), houve uma tentativa da burguesia industrial de ensaiar um projeto de capitalismo autônomo na América Latina, com cooptação das massas urbanas, proposição de reforma agrária, enfim, um projeto desenvolvimentista e populista de capitalismo nacional. Porém, esta burguesia industrial não conseguiu pressionar a burguesia agro-mercantil (latifundiários), por um lado, e os grandes monopólios internacionais (empresas transnacionais), por outro, e acabou desistindo de seus projetos. Desta forma, a burguesia agro-mercantil atrelada ao comércio internacional e submetida ao intercâmbio desigual, alia-se à burguesia industrial, detentora de mercados pequenos e protegidos, e que ainda divide lucros com o capital estrangeiro, para por em prática uma exploração ainda maior da força de trabalho urbana e rural, como mecanismo defensivo para garantir seus lucros. Trata-se da "superexploração do trabalho".

Desta forma, a superexploração do trabalho afirma-se como o "princípio fundamental do sistema subdesenvolvido". Além disso, esta se intensifica com a associação da burguesia local ao capital estrangeiro, o que resulta numa 
exploração da periferia pelo centro (isto é, o desenvolvimento capitalista integrado assentado na superexploração do trabalho) que inviabiliza os regimes liberais democráticos do pós-guerra e abre caminho para as ditaduras tecnocrático-militares dos anos 1960 e 1970. A redemocratização, sob a batuta neoliberal, nos anos 1980 e 1990, continua e aprofunda ainda mais a dependência e a vulnerabilidade externa das economias da região, devido à abertura dos mercados ao comércio internacional, à desregulamentação do mercado de trabalho, e às privatizaçóes.

Para fazer frente a esta situação acima descrita podem ser consideradas duas hipóteses: revolução ou capitalismo de Estado, como bem indica Florestan Fernandes. Para haver uma revolução são necessárias condições objetivas que não parecem evidentes, hoje em dia, nos países latino-americanos, principalmente diante do refluxo político que o movimento socialista passa desde a queda do muro de Berlim e o fim da URSS. Há, sem dúvida, condições sociais para indignação, mas daí a acontecer uma revolução política é improvável. Resta, portanto, o caminho da reforma social para produzir as transformaçóes necessárias, que poderão ou não levar a uma revolução social no sentido amplo, isto é, um desenvolvimento que altere a atual correlação de forças da estrutura de classes. Este caminho da reforma social na América Latina passa, necessariamente, pelo Estado. Se os projetos de capitalismo autônomo e capitalismo associado faliram, ao capitalismo dependente ainda pode-se contrapor uma alternativa de um capitalismo desenvolvimentista de Estado, nos moldes de um sistema de oportunidades sociais que se cristalizou no Leste Asiático. Parece ser essa a via passível de ser ensaiada pelos atuais governos de centro-esquerda na América Latina.

\section{Padrões de inserção e desenvolvimento: Leste Asiático}

No Japão, com o fim da era Tokugawa, em 1868, tem início a restauração Meiji, que promoveu a centralização política nas mãos do Imperador e sua corte. O novo governo levou a cabo uma reforma social que enfraqueceu principalmente os samurais, ao extinguirem-se todos os seus privilégios. As terras dos senhores feudais também foram concentradas pelo Imperador em 1870, transformando-se em prefeituras. A educaçáo foi reformulada de acordo com os modelos europeus e foi instituída a educação compulsória. $\mathrm{O}$ 
setor militar foi fortalecido com a modernização do exército e da marinha. Indústria e transportes receberam incentivos e investimentos. Reformou-se o sistema financeiro e instituiu-se o Banco do Japão. A primeira constituição ao estilo europeu data de 1889. Com as vitórias nas guerras Sino-Japonesa (1884-85) e Russo-Japonesa (1904-05), o Japão anexou territórios, inclusive toda a Coréia em 1910, atrelando-os, a partir de então, ao desenvolvimento econômico japonês. Em 1912 morre o Imperador Meiji e a era de reformas acaba, deixando como legado um Estado moderno e unificado, além do poderio militar mais forte da Ásia.

Na Primeira Grande Guerra, o Japão luta ao lado dos Aliados, respeitando os tratados firmados com a Inglaterra. Mas com o terremoto de Tóquio, em 1923, e com a crise econômica de 1929, boa parte da população japonesa - que dobrara em menos de um século - enfrentou fome e miséria. Diante dessa situação, ganhou força o ultranacionalismo que defendia a expansão territorial. Assim, o Japão, seguindo os passos das potências ocidentais, obriga a China a assinar tratados econômicos e políticos injustos e, em 1931, invade a Mandchúria. Em 1937 explode a Segunda Guerra Sino-Japonesa, que dura até 1945. Antes, em 1940, o Japão havia firmado pactos com os regimes fascistas da Alemanha e da Itália, além de invadir o Vietnã. Em 1941 atacou os EUA no Havaí (Pearl Harbour), fazendo com que esta potência entrasse na Segunda Guerra Mundial. Depois de perder gradualmente todos os territórios conquistados (a totalidade do Sudeste Asiático e o Pacífico, que constituía a "Esfera de Co-Prosperidade Asiática"), o Japão capitula sob o poder das bombas atômicas de Hiroshima e Nagasaki. Permaneceu então ocupado pelos Aliados por sete anos seguidos após sua rendição incondicional.

Durante o governo de transição, sob a égide norte-americana, foram os zaibatsu - holdings industriais e financeiras, que cresceram com as guerras japonesas - os principais beneficiários da transferência, estimada em 10 bilhóes de dólares em ativos, promovida para incentivar os negócios e retribuir o apoio ao regime (VADNEY, 1992, p. 77). Mais ainda, graças ao instinto de autopreservação da elite japonesa, que controlava os zaibatsu, estes preferiram cooperar com o inimigo para não sofrer represálias. Como corolário, as forças de ocupação, representadas pelo General McArthur, 
proclamaram uma nova constituição que, entre outras reformas políticas,: manteve a monarquia, mas sob a forma de um regime monárquico constitucional parlamentarista, e negou a possibilidade do país reconstruir seu poderio militar. As forças de ocupação decidiram, portanto, "manter a ordem”, preservando a classe dominante do país, se necessário usando até o próprio exército norte-americano para reprimir greves "desestabilizadoras". Evitou-se assim uma ruptura maior com a antiga ordem social na sociedade japonesa. Desta forma, a introdução do sufrágio universal e das leis de reforma agrária foram mudanças que se comprovaram importantes, mas circunscritas a um contexto que não mudou substancialmente. Os expurgos afetaram indivíduos, principalmente militares, mas a burocracia, o sistema político e o setor empresarial permaneceram intactos, apesar da sua responsabilidade na implementação da guerra e das suas atrocidades. Foram exatamente estes setores que conduziram o desenvolvimento notável da economia japonesa no pós-guerra, quando, por exemplo, a população camponesa foi reduzida de 52,4\% para 9\%, entre 1947 e 1985 (HOBSBAWM, 1995, p. 285).

Temos, então, um conjunto de reformas modernizadoras que resguardam a classe dominante quase na sua totalidade. A reforma agrária feita sob ocupação norte-americana, depois da Segunda Grande Guerra, é uma reforma em bases capitalistas, semelhante à reforma agrária da Coréia do Sul, realizada entre 1953 e 1956, depois da guerra da Coréia, igualmente pelos norte-americanos. Aliás, com a Guerra da Coréia (1950-53), o Japão teve a oportunidade de reconstruir sua economia nacional. Contando ainda com o apoio de acordos comerciais com as potências econômicas, a economia japonesa tornou-se, ela mesma, uma potência. Durante a Guerra Fria, a presença militar norte-americana aumentou nas suas 50 bases existentes no Japão, e estimulou-se o anticomunismo como forma de contenção da China Popular e da URSS. O Japão restabeleceu relações diplomáticas normais com a China somente após a aproximação sino-norte-americana, em 1972.

$\mathrm{O}$ rápido desmantelamento das restriçóes à mobilidade dos fatores, entre outras transformaçóes radicais que se seguiram imediatamente após a Segunda Guerra Mundial, ressalta o papel da intervenção do Estado na industrialização, fenômeno que ocorre tanto no Japão como em todo o Leste Asiático. Na verdade, hoje em dia, todas as economias desses países têm um 
padrão de desenvolvimento comum, que une uma estratégia de integração com a economia mundial baseada no rápido crescimento e na eficiente alocação de recursos, ambos capitaneados pelo Estado.

Analisando esta experiência da região com relação à acumulação de capital no processo de industrialização acelerada, Akyüz, Chang e Kozul-Wright (1999, p. 4-36) introduzem os conceitos de "nexo lucro-investimento" e "nexo exportação-investimento" para apontar a interdependência de elementos-chave no processo de desenvolvimento do Leste Asiático.

A importância do "nexo lucro-investimento" deriva do fato de que toda melhoria das condiçóes de vida ao longo do tempo somente pode ser conseguida por meio do aumento sustentado da produtividade, o que pressupóe aumento dos investimentos em plantas, equipamentos, infra-estrutura, educação, e Pesquisa e Desenvolvimento (P\&D). Para este aumento de produtividade, os autores vêm a liberalização doméstica acelerada e a total integração com a economia mundial como fatores importantes, que garantiram um ambiente macroeconômico pró-investimento, no qual se sacrifica o consumo mas não o investimento.

Além disso, os incentivos concedidos pelo Estado para encorajar os investimentos são considerados essenciais. Um leque de incentivos fiscais é usado para suplementar os lucros das corporações e promover a acumulação de capital. $\mathrm{O}$ comércio e as políticas financeiras e de mercado também são usadas para criar rendimentos e aumentar os lucros corporativos. Entre estas estão: proteçóes, controles sobre juros e crédito, concorrência administrada, encorajamento de fusões, restrições a indústrias estrangeiras, aquisição de tecnologia, e promoção de cartéis com o objetivo de especialização, de exportação e de criação de standards. Assim, a poupança corporativa tem um importante papel no aumento da acumulação de capital. Mais ainda: para garantir os investimentos produtivos, restringiu-se o consumo de produtos de luxo e a fuga de capitais nos estágios iniciais do desenvolvimento. Esse conjunto de açóes criou uma dinâmica econômica com "nexo lucroinvestimento".

Já o "nexo exportação-investimento" presente nessas economias direcionou toda essa quantidade de recursos acumulada de forma a promover estratégias de mercado orientadas "hacia afuera", ou seja, com o objetivo de exportar. 
Com isso, puderam ser superados os constrangimentos do balanço de pagamentos em economias sem um significativo parque de bens industriais. Como os recursos das crescentes exportaçóes eram encaminhados para o aumento da poupança doméstica, garantiu-se que a expansão da produção local se traduzisse em maiores investimentos de maneira sustentada, o que não ocorreu no caso latino-americano. Desta forma, houve um aumento continuado das exportaçóes, da poupança doméstica e do investimento, em termos absolutos e com relação ao PIB. Vejamos o exemplo da Coréia: 3,3 de poupança; 10,0 de investimento; e 2,0 de exportaçóes (todos como porcentagem do PIB) no período que vai de 1951 a 1960, e 34,7; 37,1; e 28,6 respectivamente, no período de 1991 a 1994.

É preciso sublinhar, porém, que este desenvolvimento se construiu com base nas indústrias tradicionais com mão-de-obra barata e sem treinamento. Daí a importância desses países terem promovido o investimento ligado ao estabelecimento do capital doméstico e de indústrias de bens intermediários, buscando o upgrade tecnológico. Aqui, outra vez, a presença estatal é fundamental para a construção da capacidade tecnológica nacional, industrial e até empresarial, o que se conseguiu com políticas orientadas para a P\&D local, incluindo subsídios financeiros, restrições e créditos. É preciso dizer também que a integração com a economia mundial deu-se de maneira progressiva, pois foi pensada estrategicamente, na medida das necessidades setoriais específicas. Esta integração estratégica não foi confinada ao comércio, mas incluiu também a transferência de tecnologia.

Mais ainda, atrás da administração bem sucedida dos rendimentos no Leste Asiático, está um processo profundo e amplo de construção de uma rede de instituições governamentais e privadas consistente com a estratégia de desenvolvimento, que incluem uma administração pública meritocrática e ligaçôes formais e informais com a classe empresarial (EVANS, 1993, p. 107 156). Desta forma, o processo de desenvolvimento resultou na organização e evolução de uma burguesia empresarial local e de grandes e diversificadas corporações (keiretsus no Japão e chaebols na Coréia). As ligações institucionais destas corporaçóes com o setor financeiro permitiram a socialização dos riscos por meio dos empréstimos bancários.

$\mathrm{O}$ ambiente propício para investimentos muito se beneficiou também 
de uma distribuição de renda favorável e mais eqüitativa, conseguida em grande parte pelas reformas agrárias. You (1999, p. 37-65) afirma que a baixa desigualdade e os grandes lucros coexistem, no Leste Asiático, basicamente devido à incomum distribuição da riqueza igualitária. Neste particular, três fatores são destacados:

1.Em primeiro lugar, a excepcional distribuição igualitária inicial da riqueza resultante das reformas do período pós-guerra. A reforma agrária e a acelerada expansáo do emprego no setor moderno da economia (indústrias de exportação intensivas no fator trabalho) são explicações plausíveis para essas condiçôes iniciais favoráveis;

2.Em segundo lugar, a dinâmica keynesiana do processo de acumulaçáo, na qual os lucros têm um papel crucial como fonte de poupança e incentivo ao investimento; e

3.Por último, o fato de uma alta desigualdade na distribuição funcional da renda (entre capital e trabalho) andar, lado a lado, com uma baixa desigualdade na distribuição pessoal da renda (medida pelo Índice de Gini), fato este atribuído à distribuiçáo inicial igualitária da riqueza e à propensáo a poupar dos domicílios de baixa renda.

Houve certamente, ao lado de uma estratégia de livre comércio buscando vantagens comparativas para as exportaçóes intensivas em trabalho, uma preocupação com o rápido crescimento do emprego assalariado e com o aumento dos salários. You defende que a expansáo sustentada do emprego e da produtividade foi fundamental na manutenção do modelo de crescimento com igualdade, num processo que envolveu muito mais fatores do que o livre comércio. O trade-off do modelo de crescimento com igualdade pode ser creditado, portanto, à reforma agrária e às medidas para assegurar que os lucros sejam poupados e reinvestidos. A acelerada acumulaçáo de capital e a rápida expansão dos empregos possibilitaram um também rápido crescimento da renda, mais eqüitativamente distribuída do que em outras regióes.

Evans (1999, p. 66-86) acrescenta que o "modelo amigável com o mercado" 
(market-friendly) (Banco Mundial), o "modelo da política industrial" (JOHNSON, 1992) e o "modelo de nexo lucro-investimento" (AKYÜZ, 1998), têm em comum um centro robusto de pré-requisitos institucionais envolvido, o que diz respeito a um aparato burocrático excepcionalmente capaz e relativamente independente para que estes modelos funcionem, além de laços dinâmicos entre governo e o mundo dos negócios. Evans chama essa aparente contradição da combinação de ligações estreitas com o empresariado com a independência requerida de "embedded autonomy" (algo como "autonomia embutida"). Na verdade, para haver uma coerente ação pública, as políticas estatais requerem uma estrutura que tenha a capacidade de coordenar e que resolva questóes de jurisdição, o que pode ser encontrado em torno de uma "agência piloto" que burile iniciativas de desenvolvimento, como é o caso do MITI no Japão e do Escritório de Planejamento Econômico na Coréia.

Acreditamos que estas estruturas organizativas, permanentemente em construção, devem muito ao passado histórico e à organização social nestes países. Não é possível entender o Estado, no Leste Asiático (ou em qualquer parte), descolado da realidade social existente em cada Nação. Não se trata aqui de fazer a apologia de "valores asiáticos", o que Sen (1998) também critica, mas de compreender que a cultura social favoreceu o desenvolvimento da estrutura de poder da forma como ele se deu, influenciando as organizaçóes que surgiram nesse processo, além de determinar a criação do sistema de oportunidades sociais. Afinal, "cultura organizacional" das empresas tem a ver com cultura propriamente dita. Isto significa dizer que as burocracias são fruto de processos sociais que se diferenciam de nação para nação. $\mathrm{O}$ desenvolvimento também. O fato é que, para nós, as experiências do Leste Asiático merecem atenção pela capacidade que tiveram de implantar o modo de desenvolvimento japonês-asiático, com a dinamização do capitalismo desenvolvimentista de Estado na consecução de conquistas nacionais, tais como o crescimento com igualdade social. Isto deve ser considerado, no contexto latino-americano, como opção histórica com mais justiça social, no caso de se considerar somente alternativas dentro do modo de produção capitalista. 


\section{Peculiaridades da China}

Vamos analisar agora ao caso especial da China (ESTENSSORO, 2003). Em 1949, os comunistas estabeleceram a República Popular da China e promoveram também uma reforma agrária, assim como na Coréia do Norte, em 1956. Estas reformas caracterizaram-se pelo combate aos latifundiários e à nobreza rural, enquanto nas cidades houve um período de cooptação da burguesia nacional com a promoção do "capitalismo nacional", pelo menos até 1953 , ano do primeiro plano qüinqüenal,

A expropriação da burguesia ocorreria a partir de 1953, até completar-se em 1956. No campo, contudo, desde a Lei da Reforma Agrária de 1950, a nobreza rural proprietária e os camponeses ricos $(6 \%$ do total $)$ - focos de subversão anticomunista - foram os alvos prioritários a serem combatidos. Fazendas coletivas foram estruturadas como o objetivo de aumentar a produtividade, embora, nesse meio tempo, o governo tenha redistribuído 117 milhóes de hectares de terra arável para aproximadamente 300 milhóes de camponeses, isto é, uma média de um terço de acre para cada um. Foi uma reforma agrária com mais ganhos políticos do que econômicos, já que as pequenas unidades econômicas não tinham capacidade para adquirir maquinaria, por exemplo. Tratou-se, portanto, da criação em massa de pequenos proprietários, em consonância com a fase de "capitalismo nacional" nas cidades.

A transição para o socialismo foi anunciada em 1953, com o primeiro plano qüinqüenal, e teve início a coletivização da agricultura. A cooperativização dos agricultores espalhou-se rapidamente por todo o campo, fortalecendo Mao Tsé-tung e sua facção diante dos modernizadores (Li Shaoqi e Deng Xiaoping), que detinham um forte apoio entre os burocratas dos programas de industrialização urbana. A cooperativização parecia ter o apoio de todo o campo, base socio-política de Mao Tsé-tung, e, por volta de 1956, 90\% da população rural estava organizada em 485.000 cooperativas ou fazendas coletivas.

No "Grande Salto para Frente" tentou-se aumentar a produtividade no campo - onde vivia $80 \%$ da população até a década de 1980 - criando pequenas indústrias nas 24.000 comunas rurais (que em média tinham 30.000 pessoas). Foi a forma encontrada para promover o desenvolvimento utilizando 
intensivamente o abundante fator trabalho e diminuindo a necessidade de investimentos de capital (inclusive a ajuda soviética, que retraiu-se depois da cisão sino-soviética após o XX Congresso do PC da URSS). Desta forma, o planejamento foi encorajado a adequar-se ao tamanho das comunas, que era a instituição mais identificada com o "Grande Salto para Frente".

No período seguinte, apesar da grande efervescência política da "Revolução Cultural”, pode-se dizer que esta não alterou significativamente a distribuição da riqueza nem a posição social dos diferentes grupos da população. Com a morte de Mao Tsé-tung, em 1976, Deng Xiaoping conseguiu supremacia nas instâncias políticas chinesas, abrindo caminho para as reformas modernizadoras que se seguiram, incluindo o desmantelamento completo do sistema de comunas no campo, a possibilidade de abrir negócios privados (que saltam de 100.000, em 1978, para 17 milhóes, em 1985), e a abertura para o Japão e o Ocidente como meio de aumentar o comércio e adquirir tecnologia (VADNEY, 1992, p. 164-181, p. 343-359).

Como vemos na Tabela 3, a pobreza aumentou entre 1987 e 1998 em todo o mundo de maneira agregada, porém diminuiu na China no mesmo período, onde 90 milhóes de pessoas superaram a linha de pobreza de um dólar por dia por pessoa. Calcula-se que o número de chineses que deixou de ser pobre - segundo esse critério - ultrapasse os 200 milhóes desde o começo das reformas econômicas, em $1978^{3}$. Atribuir este decréscimo da pobreza apenas à expansão do capitalismo naquele país continental seria certamente indevido, principalmente se considerarmos que, com o desmantelamento do comunismo burocrático ${ }^{4}$ no Leste Europeu e na Rússia, a penetração do sistema capitalista tem promovido até agora o efeito inverso naquela região (CORNIA, 1994, p. 569-607).

\footnotetext{
${ }^{3}$ As reformas na China se iniciaram com a substituição da agricultura coletiva pelo acesso do camponês ao uso da terra e continuaram com as reformas institucionais, econômicas, etc. que permitiram, entre outras coisas, a entrada de capitais estrangeiros na China em quantidade excepcional. Shicheng sustenta que as reformas na China vêm para aperfeiçoar o sistema socialista chinês e desenvolver a "economia mercantil planificada socialista" ou socialismo de mercado na versão chinesa (SHICHENG, 1992).

${ }^{4}$ Usamos comunismo burocrático como sinônimo de socialismo real. Max Weber utilizava a expressão socialismo de Estado ou socialismo burocrático. Tragtenberg usa coletivismo burocrático para caracterizar a formação econômico-social da URSS, do Bloco Oriental, China atual e Cuba. "O capitalismo de Estado, ou melhor, o processo de modernização levado a efeito por uma elite industrializante sob a direção de um partido único, implica nos seus inícios, já a burocracia. [...] Esta burocracia possui o Estado como propriedade privada" (TRAGTENBERG, 1992, p. 40-41, p. 86).
} 
Tabela 3 - Pobreza por regiáo, anos selecionados, 1987-1998

\begin{tabular}{|l|c|c|c|c|c|}
\multicolumn{7}{c}{ Pessoas vivendo com menos de US\$1 por dia (milhóes) } \\
\hline \multicolumn{1}{|c|}{ Regiáo } & $\mathbf{1 9 8 7}$ & $\mathbf{1 9 9 0}$ & $\mathbf{1 9 9 3}$ & $\mathbf{1 9 9 6}$ & $\mathbf{1 9 9 8}$ \\
\hline leste Asiático e Pacífico & 417,5 & 452,4 & 431,9 & 265,1 & 278,3 \\
\hline Europa e Ásia Central & 1,1 & 7,1 & 18,3 & 23,8 & 24,0 \\
\hline América Latina e Caribe & 63,7 & 73,8 & 70,8 & 76,0 & 78,2 \\
\hline Oriente Médio e Norte da África & 9,3 & 5,7 & 5,0 & 5,0 & 5,5 \\
\hline Sul da Ásia & 474,4 & 495,1 & 505,1 & 531,7 & 522,0 \\
\hline África Sub-Sahariana & 217,2 & 242,3 & 273,3 & 289,0 & 290,9 \\
\hline Total Excluindo China & 879,8 & 915,9 & 955,9 & 980,5 & 985,7 \\
\hline China & 303,4 & 360,4 & 348,4 & 210,0 & 213,2 \\
\hline Total & $1.183,2$ & $1.276,4$ & $1.304,3$ & $1.190,6$ & $1.198,9$ \\
\hline
\end{tabular}

FONTE: Banco Mundial, 2001.

$\mathrm{Na}$ verdade, o crescimento econômico invejável da China ${ }^{5}$ pode ser atribuído, em grande parte, ao Estado e às empresas coletivas de vilas e comunidades (township and village enterprises, TVEs), nascidas a partir da reforma de 1978. Estas últimas compóem um setor público não-estatal que integra o sistema econômico misto do país. Este compreende, além das TVEs, as grandes empresas e bancos estatais (state-owned enterprises, SOEs) e o setor privado, incluindo as corporaçóes transnacionais (Empresas Transnacionais, ETNs). Para entender a importância desses setores podemos dizer que, ao longo dos anos 1980, 80\% do investimento bruto, que se situava acima de $35 \%$ do PIB, era feito pelo setor público - TVEs (15\%) e SOEs (65\%) (MEDEIROS, 1999, p. 96).

Uma das razões da diminuição da pobreza na China - que é basicamente uma pobreza rural - é certamente o crescimento espetacular, principalmente o agrícola (7,4\% entre 1978-84; comparado com 2,5\% no período 1952-78) (ZHANG, 1993), aliado ao desenvolvimento destas empresas rurais (TVEs), que criaram milhões de empregos. Hoje essas empresas empregam mais de $1 / 4$ da força de trabalho rural e contribuem em $40 \%$ da renda per capita rural

\footnotetext{
${ }^{5} \mathrm{O}$ crescimento médio anual do PIB, na década de 1980, foi de 10,1\% e, nos anos 1990, de 10,7\% (Banco Mundial). Dado impressionante principalmente se levarmos em conta que, antes das reformas, de 1952-1978, o crescimento médio anual foi de 4,4\% (Maddison). Da mesma forma, entre 1978 e 1998, o PIB per capita cresceu a uma média anual de 8,8\%. Também depois das reformas, as exportações de bens e serviços cresceram anualmente 21,1\% e, entre 1988 e 1998, cresceram 14,5\% ao ano. Esta performance não tem paralelo nas economias dos países com um peso econômico comparável à China (BANCO MUNDIAL, 2000; Maddison citado em MEDEIROS, 1999).
} 
(YAO, 1999, p. 104-130).

Cabe assinalar, no entanto, que a desigualdade tem aumentado ${ }^{6}$ no país, em grande parte pela dinâmica da economia das cidades em detrimento do campo (desigualdade urbano-rural) e pela pujança econômica de algumas regióes, principalmente as costeiras Zonas Econômicas Especiais (ZEEs)

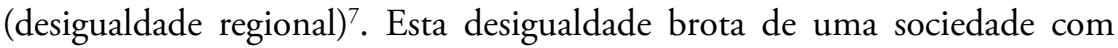
uma base de igualdade prévia muito grande (socialização da educação e da saúde, reforma agrária, etc.) que enfrentou um boom de produtividade $^{8}$ a partir de reformas que transformaram a economia e as instituiçóes chinesas, num esforço para inserir a economia do país no mercado mundial.

Não está demais acrescentar que esta integração ao mercado mundial simbolizada pela entrada da China na OMC, em 2001 - está sendo conduzida na tentativa de preservar certos interesses nacionais, dos quais um deles parece ser a determinação em erradicar a pobreza no país, revertendo grande parte do crescimento econômico para esse fim, por meio de economias de escala e políticas públicas. Talvez seja possível, com um crescimento sustentado de $10 \%$ ao ano, retirar os restantes 213,2 milhóes de chineses da miséria (abaixo da linha de pobreza de um dólar por dia por pessoa) em algumas décadas, apesar da desigualdade e do desemprego crescentes. Porém, não é certo que esse crescimento econômico seja sustentável, uma vez que grande parte desse processo se dá pelo enxugamento do Estado, tanto da sua regulamentação institucional quanto da sua base econômica (SOEs), causando inclusive desemprego e miséria nas cidades.

Assim, até mesmo o processo de melhoria do desenvolvimento humano

\footnotetext{
${ }^{6}$ O índice de Gini da China passou de 21,2, em 1978, para 32,0, em 1994 (Yao). Chen e Wang afirmam, após verificar diversos estudos, que: "There is a consensus among these studies that, even though about 270 million people were lifted out of poverty since the reforms started in 1978, the benefits of growth are unevenly distributed. Inequalities in income and consumption have been worsening, especially in the recent years. The Gini coefficient, a low 28.8 in 1981, reached 41.5 in 1995, a level similar to that of the United States. The rural-urban divide is increasing, regional disparities are widening and access to opportunities is becoming less equal" (YAO, 1999; CHEN, WANG, 2001).

7 "To fully understand poverty in China, three important factors need to be examined: income inequality for the whole country, especially for the rural population (including those working in the cities but classified as rural people [by the Government]; rural-urban income inequality; and regional income inequality" (YAO, 2000, p. 447-474).

8 "A sharp, sustained increase in productivity (that is, increased worker efficiency) was the driving force behind the economic boom." (HU; KAHN, 1997). Maddison estima que a taxa de crescimento anual da produtividade agrícola passou de 0,17, no período 1952-78, para 4,27, no período 1978-95 (MEDEIROS,1999; HU, KHAN, 1997, p. 1-10).
} 
é posto em xeque pelo crescimento das desigualdades ${ }^{9}$, além da falta de democracia política ${ }^{10}$. $\mathrm{Na}$ verdade, as melhorias sócio-econômicas não foram acompanhadas por uma democratização do aparato burocrático. De maneira pessimista, podemos vislumbrar, no desenvolvimento da sociedade chinesa, um regime de Estado autocrático combinado com uma economia hegemonizada pelo processo de globalização comandado pelas corporaçóes transnacionais.

Enfim, a versão chinesa para socialismo de mercado e a participação pública não-estatal das TVEs, últimas grandes promessas do "socialismo real", podem não se firmar como alternativa real ao capitalismo monopolista, à dependência e à burocratização. Mesmo porquê os desafios ainda são consideráveis: o número de pessoas em torno da linha de pobreza na China é muito grande, como mostram os números da população abaixo de US\$ 2 por dia por pessoa. Esta população de pobres representa uma divida social de uma magnitude cinco vezes maior do que a brecha de pobreza da população abaixo de US\$ 1 por dia por pessoa, isto é, uma parcela cinco vezes maior da renda nacional seria necessária para retirar os pobres da miséria, se considerarmos uma linha de pobreza de dois dólares por dia por pessoa..

Este problema social pode ser considerado superado nos EUA, na Coréia e no Japão, enquanto que na América Latina ainda é uma questão que nos qualifica como subdesenvolvidos. Entretanto, a quantidade de pessoas abaixo da linha de pobreza de US\$ 2 na China é distinta de países como Brasil e México, fazendo com que o patamar da brecha de pobreza (poverty gap) seja menor nestes últimos.

Como vemos na Tabela 4 a seguir, a desigualdade (ou distribuição de renda) na América Latina e nos EUA é maior do que na Ásia. No caso latinoamericano, supera o Índice de Gini de 48, chegando a 60 no caso brasileiro. Reparemos também que são os paises latino-americanos (Brasil e México)

\footnotetext{
${ }^{9}$ Embora reconheça que as reformas na China quadruplicaram o PIB per capita de 1/5 da humanidade em 20 anos, Khan afirma que a preocupação do governo com a taxa de acumulação impede que se dê a devida atenção ao desperdício de recursos, à crescente desigualdade e ao correto combate da pobreza, que deveria inclusive tratar de problemas como o dos 72 milhões de migrantes internos existentes em 1995 (KHAN, 1998).

${ }^{10}$ Apesar do sistema experimental de eleições de chefes de vilas, a partir de 1987, Lew (1999) afirma que "le 'socialisme réel' chinois repose sur une structure autoritaire, aujourd'hui plutôt décentralisée, où la tutelle de l'Etat (ou de l'Etat dans ses formes locales et regionales) s'exerce encore de façon arbitraire, souvent sans considération pour les besoins et exigences des habitants".
} 
que têm os $10 \%$ mais ricos com mais de $40 \%$ da renda nacional. Os países asiáticos, portanto, caracterizam-se por serem mais igualitários. Notemos, por exemplo, o paralelismo da distribuição de renda entre EUA e China. Apesar do imenso desenvolvimento do primeiro, os $20 \%$ mais pobres na China têm uma parcela da renda um pouco maior do que os $20 \%$ mais pobres dos EUA, sendo que o índice de Gini e a parcela que cabe aos 20\% mais ricos são semelhantes nos dois países. Ora, China é um país do Terceiro Mundo, os Estados Unidos são o centro da economia mundial. Este país deveria ter um desenvolvimento social, em termos de distribuição de renda, semelhante ao japonês, cujos indicadores de desigualdade são muito melhores do que os norte-americanos.

Tabela 4 - Distribuição da renda

\begin{tabular}{|c|c|c|c|c|c|c|c|c|c|}
\hline País & Ano & Gini & $10 \%$ & $20 \%$ & $\begin{array}{c}2^{\mathbf{o}} \\
20 \%\end{array}$ & $\begin{array}{c}3^{\circ} \\
20 \%\end{array}$ & $\begin{array}{c}4^{\mathbf{0}} \\
20 \%\end{array}$ & $20 \%$ & $10 \%$ \\
\hline EUA & 1993 a,b & 40,8 & 1,8 & 5,2 & 10,5 & 15,6 & 22,4 & 46,4 & 30,5 \\
\hline China & 1998 c,d & 40,3 & 2,4 & 5,9 & 10,2 & 15,1 & 22,2 & 46,6 & 30,4 \\
\hline Japão & 1993 c,d & 24,9 & 4,8 & 10,6 & 14,2 & 17,6 & 22,0 & 35,7 & 21,7 \\
\hline Coréia & 1993 a,b & 31,6 & 2,9 & 7,5 & 12,9 & 17,4 & 22,9 & 39,3 & 24,3 \\
\hline Brasil & $1996 \mathrm{c}, \mathrm{d}$ & 60,0 & 0,9 & 2,5 & 5,5 & 10,0 & 18,3 & 63,8 & 47,6 \\
\hline México & $1995 \mathrm{c}, \mathrm{d}$ & 53,7 & 1,4 & 3,6 & 7,2 & 11,8 & 19,2 & 58,2 & 42,8 \\
\hline Argentina* & 1996 c,d,e & 48,0 & 1,5 & 4,3 & 8,6 & 13,2 & 20,8 & 52,9 & 35,9 \\
\hline
\end{tabular}

FONTE: Banco Mundial, 2000.

* BID (1998, p. 25)

a. Refere-se a partes de consumo por percentual da população.

b. Ordenado pelo consumo per capita.

c. Refere-se a partes de renda por percentual da população.

d. Ordenado por renda per capita.

e. Refere-se apenas à Grande Buenos Aires.

De fato, o modo de desenvolvimento japonês-asiático apresenta um sistema de oportunidades sociais e econômicas que o torna estruturalmente mais igualitário, produzindo menores desigualdades sociais e menos pobreza. Este modelo carrega, mesmo dentro do contexto da crise financeira mundial, elementos estruturalmente eqüitativos, onde as metas sociais e coletivas 
têm preeminência e dominância, como uma marca histórica das sociedades do Leste Asiático. Dá-se assim ao capitalismo desenvolvimentista de Estado um potencial de dinamismo qualitativamente diferenciado. Este elemento estrutural qualitativamente singular, por razões históricas, está na construção de instituiçóes de oportunidades sociais e econômicas, que dão ênfase à educação básica e à assistência elementar à saúde, para não falar da implantação de reformas agrárias eficazes. Estas instituições sociais ampliam e facilitam a participação econômica da maioria da população do Leste Asiático.

\section{Análise dos indicadores}

Esta seção procura evidências estatísticas do sistema de oportunidades sociais do Leste Asiático, bem como características do seu capitalismo desenvolvimentista de Estado, comparado com o modo de desenvolvimento anglo-americano. Os dados oficiais divulgados pelas instituiçóes internacionais revelam claramente as tendências divergentes dos modos de desenvolvimento japonês-asiático e anglo-americano, com a América Latina incluída neste último. Resumimos aqui as tendências básicas apontadas para o desenvolvimento econômico e social dos países selecionados pelos dados existentes na publicação World Development Indicators, do Banco Mundial. Já os gráficos apresentados a seguir foram feitos a partir de dados extraídos da publicação Economic Outlook 76 Database, da OCDE.

Pelos números produzidos pelo Banco Mundial, a expectativa de vida era maior nos EUA, mas foi ultrapassada pela existente no Japão. Estes países partem de 70 e 68 anos, em 1960, e chegam a 77 e 81 anos, respectivamente, em 2000. Tanto Coréia como a China, que largam de patamares inferiores aos latino-americanos (54 Coréia e 36 China), chegam ao ano $2000 \mathrm{com}$ expectativa de vida igual ou superior à da América Latina. Como resultado, temos um destaque para a existência, nos EUA (12,3\%) e principalmente no Japão $(17,2 \%)$, de uma população considerável acima dos 65 anos, bem acima dos outros países, onde essa faixa etária não chega a $10 \%$. A mortalidade infantil, por outro lado, sempre foi menor também nos EUA e no Japão, que atingem impressionantes 9 e 5 mortes por 1000 nascimentos em 2000, respectivamente. Já a China, que parte de um índice altíssimo de 209 mortes, chega ao ano 2000 com uma taxa igual ao do Brasil (39). Com 
esses dois processos paralelos (menos mortalidade e maior expectativa de vida), não é de se estranhar que a China, apesar das políticas de controle de natalidade (em especial a do filho único), tenha ainda assim um aumento demográfico imenso que quase dobrou sua população entre 1960 e 2000.

O desenvolvimento econômico também possibilitou aos países asiáticos diminuir a taxa de trabalho infantil, principalmente na China, onde esta passou de 43,17\%, em 1960, para 7,86\%, em 2000. Nos EUA, Coréia e Japão este problema pode ser considerado superado, enquanto que o Brasil apresenta agora a taxa mais alta entre os países da amostra (14,43\%). No México (4,88\%) e na Argentina (2,40\%) o problema é menor, mas persiste.

Ainda sobre a força de trabalho, pode-se apontar uma outra questáo como sendo mais problemática na América Latina que na Ásia: o desemprego. Apesar das taxas baixas do México (2,9\%, em 2000) - onde talvez o desemprego existente esteja sendo encoberto pelo trabalho precário - o Brasil (9,0\%) e a Argentina (12,8\%) apresentam taxas bem maiores do que as asiáticas $(3,1 \%, 4,1 \%$ e 6,8\%). Como podemos observar no Gráfico 1 , entre as economias desenvolvidas, o Japão também apresenta menores taxas históricas de desemprego do que as economias dos EUA e da Europa, incluindo a Alemanha.

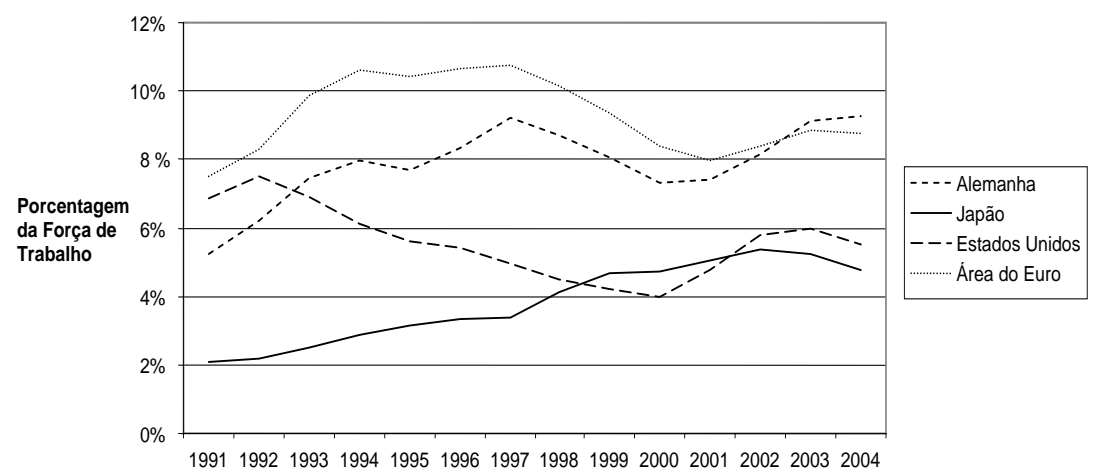

Anos

Gráfico 1 - Taxas de desemprego

Em educação, é notório o maior investimento por estudante, como porcentagem do PIB per capita, existente na Coréia (17,38\%, nos anos 1990) 
e no Japão (18,97\%), em contraste com a América Latina (10,98\% no Brasil e $8,98 \%$ na Argentina). Apesar da imensa legião de estudantes na China, esta taxa $(6,47 \%)$ chega a ser maior que a do México (6,42\%). Como resultado, temos que o analfabetismo adulto chinês que era de 48,74\%, em 1960, entra no ano 2000 com níveis compatíveis com os do Brasil (em torno de 15\%). Coréia e Argentina estão no patamar de 3\%, enquanto que nos EUA e no Japão o problema desaparece.

Os investimentos em saúde como porcentagem do PIB são maiores nos EUA (12,89\% em 1998) do que nos outros países (entre 5\% e 8\%). Este fato deve ser creditado ao alto investimento privado norte-americano em saúde, que chega a ser, em 1998, de US\$ 4.095 por pessoa (embora a parte pública do gasto em saúde é bem maior no Japão e na Europa do que nos EUA). No Japão, os gastos em saúde por pessoa (US\$ 2.243) são bem maiores do que na China (US\$ 37), onde os gastos são diluídos na sua imensa população. $\mathrm{O}$ destaque fica para os investimentos decrescentes em saúde, como porcentagem do PIB, da Argentina, embora ainda sejam os mais altos da América Latina. Como resultado, temos muito mais leitos hospitalares per capita no Japão $(16,20)$ do que nos outros países (inclusive os EUA, com 4,00), sendo que a China $(2,34)$ tem mais do que o México $(1,20)$, e a Coréia $(4,60)$ mais do que o Brasil $(3,11)$. Em saneamento básico e acesso a água potável os números favorecem a América Latina em relação à China. Nos EUA a cobertura é de $100 \%$ em ambos.

Os caminhos do desenvolvimento social no Leste Asiático e nos EUA são abertos pelo crescimento do PIB e do PIB per capita. Senão vejamos: em 1980, o PIB da China (US\$ 455 milhóes) e da Coréia (US\$ 115 milhóes) eram menores do que o PIB do Brasil (US\$ 491 milhóes) e da Argentina (US\$ 194 milhóes), e terminam por ser mais que o dobro, respectivamente, em 2000: a China com US\$ 5.019 milhões e a Coréia com US\$ 821 milhóes, contra US\$ 1.299 milhóes do Brasil e US\$ 458 milhóes da Argentina. Ou seja, trata-se de um crescimento impressionante nestes países do Leste Asiático, que alcançaram o desenvolvimento do Japão, que já era grande. Este país chega, ao ano 2000, como terceira potência em termos de PIB PPP (US\$ 3.394 milhóes), atrás da China, que teve um crescimento da sua economia em torno de $10 \%$ ao longo de 20 anos, e dos EUA (US\$ 9.612 milhóes), 
que conservou o primeiro lugar. Os EUA também mantiveram a dianteira em termos de PIB per capita, seguidos pelo Japão e Coréia. O PIB per capita Argentino era o dobro do coreano, em 1980, mas depois perde a corrida e, apesar de ser o mais alto da América Latina, representa, em 2000, menos da metade do PIB per capita japonês. A China, apesar do acelerado crescimento, ainda tem o menor PIB per capita entre os países da amostra, outra vez por causa da grande população.

Podemos verificar que a economia norte-americana tem possibilidades superiores mesmo em relação à Europa e ao Japão. O Gráfico 2 mostra os índices de crescimento do PIB real, onde vemos que os EUA têm um crescimento maior. Mesmo assim, de 1980 até a Crise Asiática de 1997, o Japão esteve à frente nas taxas de crescimento.

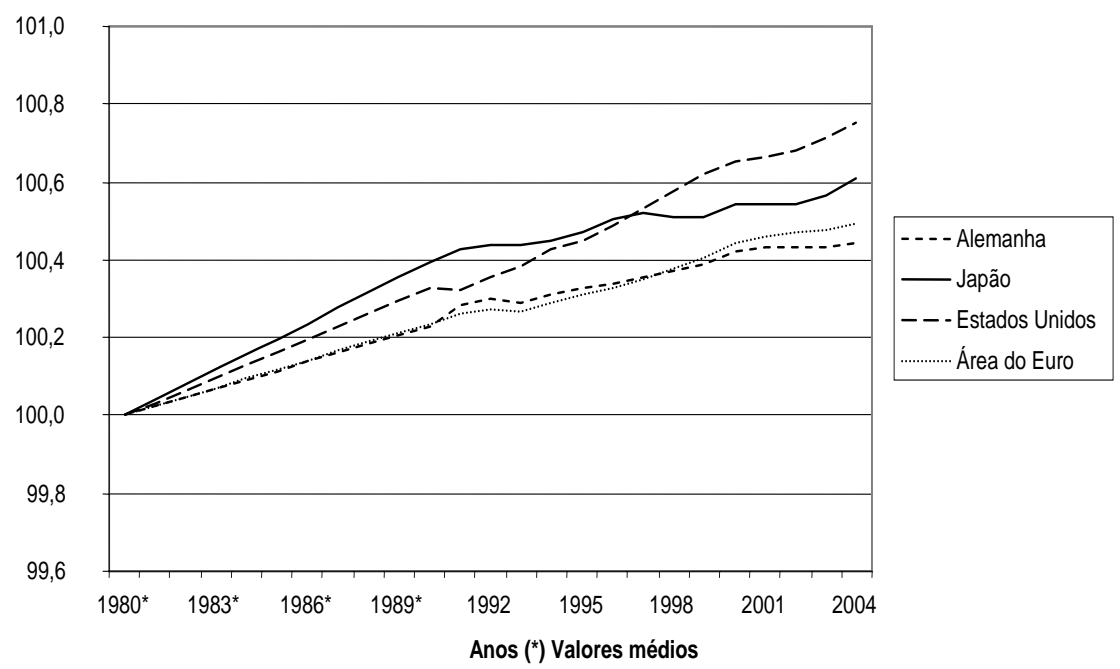

\section{Gráfico 2 - Índices do PIB real}

O crescimento econômico dos EUA e do Leste Asiático é decorrente de um conjunto de fatores econômicos que se somam, alguns dos quais listamos a seguir:

1) A formação bruta de capital fixo em relação ao PIB tem sido, ao longo do tempo, bem maior no Leste Asiático (36,1\% da China; 26,2\% do Japão; 
e 28,7\% da Coréia, em 2000) do que na América Latina (20,3\% do Brasil; 20,9\% do México; e 15,9\% da Argentina) e nos EUA (20,2\%). Porém, esta vantagem dos países asiáticos é em relação ao seu PIB nacional e não consegue superar o volume absoluto de formação real bruta de capital fixo total da economia norte-americana;

2) A poupança doméstica bruta em relação ao PIB também tem sido, historicamente, consideravelmente maior na China (39,9\% em 2000), Japão $(27,6 \%)$ e Coréia $(31,1 \%)$ do que no Brasil (19,2\%), México (21,5\%), Argentina (15,3\%) e EUA (17,9\%), o destaque fica para a Coréia que tinha apenas $2 \%$ em 1960 ;

3) Além disso, as exportações de bens e serviços em relação ao PIB são muito grandes na China $(25,9 \%$ em 2000) e na Coréia (45,0\%), números só alcançados pelo México pós-NAFTA (31,4\%). No Brasil, Argentina, EUA e Japão esta taxa está em torno a $10 \%$.

Apesar deste esforço exportador, o México se equipara ao Brasil e Argentina no balanço deficitário em conta corrente em relação ao PIB, fato que contrasta com os superávits do Leste Asiático. Este último indicador aponta o extremo endividamento dos países latino-americanos, que vêm pagando o dobro ou o triplo de juros da dívida externa, em relação ao PIB, em comparação com a China e a Coréia. Já nos EUA este indicador equivale a 4,5\% do PIB em 2000, o que representa um déficit muito grande em números absolutos, revelando o poder de compra desta potência no comércio internacional.

$\mathrm{Na}$ verdade, o problema latino-americano com sua dívida externa está longe de terminar. A dívida externa total tem crescido, na Argentina e no Brasil, até atingir 40,0\% e 51,3\% do PIB, em 2000, respectivamente, sendo que na China é de apenas 13,9\%. O decréscimo da dívida mexicana, ultimamente, fez com que esta se igualasse à proporção da Coréia, em torno de $29 \%$. A boa administração da dívida no México também conseguiu que o serviço de sua dívida sobre as exportaçóes decrescesse, até chegar a 30,2\%, em 2000, o que indica, igualmente, o esforço exportador daquele país. Porém, no Brasil e na Argentina, esse esforço foi em vão, pois o serviço total da dívida em relação às exportaçóes atingiu, em 2000, incríveis 90,7\% e 
$71,3 \%$, respectivamente, sendo que na Coréia este indicador era de $10,9 \%$ e na China 7,4\%. Japão e EUA não pontuam nesta classe de quesitos.

Por outro lado, o consumo de eletricidade per capita, indicador econômico que pode revelar o nível da atividade econômica, inclusive a atividade informal, bem como o indicador de posse de computadores pessoais (indicador de inclusão social em termos tecnológicos), é bem menor na América Latina do que nos EUA, Japão e Coréia, embora seja maior do que na China (sabemos estes indicadores são distorcidos pela imensa população chinesa). Já quanto aos gastos em Tecnologia da Informação (TI) e comunicaçóes, em relação ao PIB, o México $(3,2 \%)$ e a Argentina (4,1\%) ficaram atrás da China $(5,4 \%)$ e Coréia $(6,6 \%)$, em 2000. O Brasil (8,4\%), está à frente até dos EUA $(8,1 \%)$ e Japão $(8,3 \%)$, revelando o seu engajamento nos processos de globalização, preocupação constante dos últimos governos brasileiros. Porém, em termos absolutos, a diferença dos recursos brasileiros em comparação com os japoneses e norte-americanos pode ser deduzida pelo tamanho do PIB de cada país.

Quanto à proporção de exportaçóes de manufaturados sobre o total de exportaçôes, podemos verificar que este número é bem maior na China (88\%, em 2000), na Coréia (91\%) e no Japão (94\%), do que no Brasil (59\%) e na Argentina (32\%). O México e os EUA, ambos com 83\%, perdem para a China. Entendemos então a lógica exportadora da economia do Leste Asiático. Por outro lado, em termos de investimento direto externo (IDE) bruto, em relação ao PIB, compreendemos que Brasil, Estados Unidos, Argentina e China, nessa ordem, estão recebendo grande quantidade de recursos externos, fato que, pelo grande PIB chinês e, principalmente, norteamericano, representa um imenso volume de investimentos nesses países.

Diversos indicadores demonstram que a sociedade japonesa é mais igualitária do que as sociedades européias e norte-americana. A evoluçâo do coeficiente de Gini, que indica o grau de desigualdade entre os estratos de renda, é um claro exemplo disto. Quanto mais este índice se aproxima de zero, melhor é distribuição de renda em uma determinada sociedade. O Japão apresenta, historicamente, o coeficiente de Gini em torno de 0,25, o que significa que é uma das sociedades mais igualitárias do planeta. Verificamos também que há uma diferença crescente entre Japão e EUA neste quesito: em 1993, o coeficiente de Gini dos EUA era de 40,8, sendo que a desigualdade 
neste país é crescente desde os anos 1980.

No Brasil, a média histórica do coeficiente de Gini é de 0,60, muito acima da média destes países desenvolvidos, o que revela a nossa extrema desigualdade social. No Gráfico 3, é possível perceber a diferença de distribuição de renda segundo os estratos sociais (quintis, representando cada um $20 \%$ da população). Estes dados revelam que os estratos mais pobres do Brasil recebem menores parcelas de renda do que os estratos mais pobres dos EUA e do Japão, enquanto que os $20 \%$ mais ricos recebem muito mais, proporcionalmente, no Brasil do que nos outros países. $\mathrm{O}$ inverso ocorre no Japão. Assim, os EUA têm uma sociedade mais igualitária que a brasileira e menos igualitária que a japonesa.

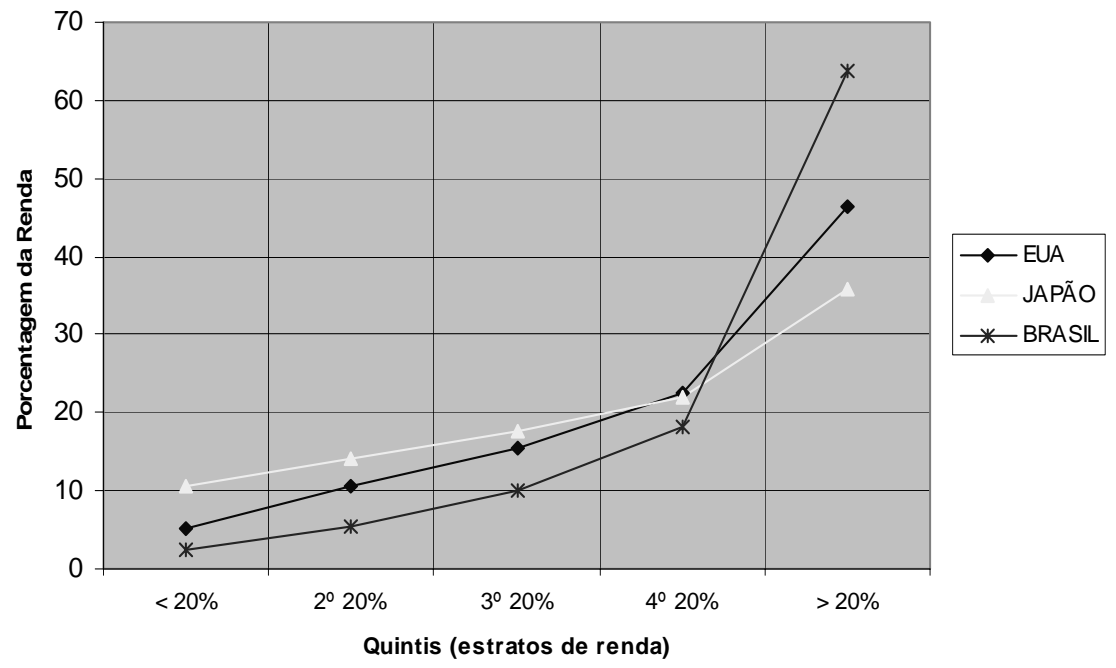

Gráfico 3 - Distribuição de renda, anos 1990

É possível comprovar que, tanto na incidência de trabalhos com baixos salários, quanto na dispersão dos rendimentos, o Japão se mostra uma sociedade com mais eqüidade social do que a norte-americana e as sociedades européias: a relaçáo entre o decil número 9, mais rico, sobre o decil número um, mais pobre, revela uma diferença de 15 vezes no Japão, enquanto que nos EUA é de aproximadamente 25 vezes. Podemos encontrar as razóes desta maior eqüidade na própria economia japonesa: além de haver maior investimento 
em educação e saúde do que na América Latina, não há problemas como o da dívida externa latino-americana. Ocorre também um grande crescimento do PIB e do PIB per capita, comparativamente com as outras economias da amostra, em função das maiores taxas históricas de crescimento da formação bruta de capital fixo em relaçáo ao PIB, de poupança doméstica bruta em relação ao PIB, e de exportações de bens e serviços em relação ao PIB. Além disso, há menores taxas históricas de desemprego, menores taxas de inflação e, conforme observamos no gráfico abaixo, maior produtividade do trabalho do que nos países europeus e nos EUA. Destacamos, novamente, a importância do crescimento sustentado da produtividade para o sucesso do regime de acumulação japonês-asiático, e igualmente para o crescimento econômico excepcional existente no socialismo de mercado chinês.

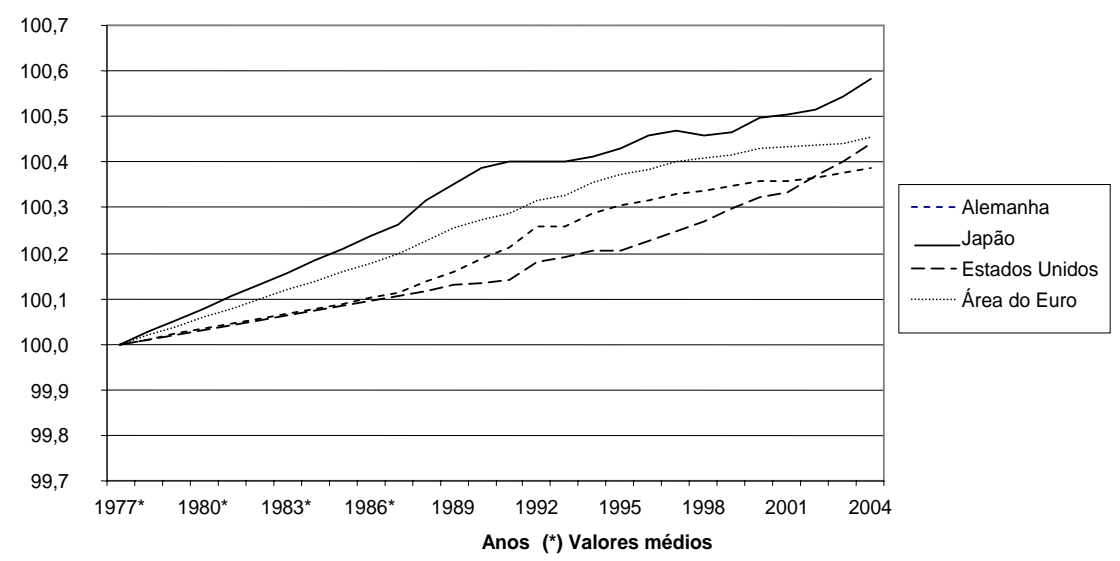

Gráfico 4 - Índices de produtividade do trabalho no setor privado

Temos, então, uma economia em expansão no Leste Asiático, puxada pelo alto desenvolvimento japonês e pelo acelerado crescimento chinês, e que se destaca claramente nos seus indicadores sociais e conjunturais ao longo do tempo, na sua comparação com o modo de desenvolvimento anglo-americano. Isto resulta num maior desenvolvimento humano e social naquela região. Apesar dos EUA terem um desenvolvimento econômico ainda maior, este se caracteriza por ser menos igualitário, pois as potencialidades de promover o desenvolvimento humano naquele país são superiores, embora sejam subutilizadas. Há, portanto, um melhor aproveitamento das possibilidades 
econômicas nos países do Leste Asiático: a boa performance econômica combina-se com a melhor utilizaçáo dos recursos, para promoverem, conjuntamente, uma arquitetura social mais democrática, no sentido de uma maior democracia econômica, isto é, maior igualdade social, como observamos no Gráfico 5.

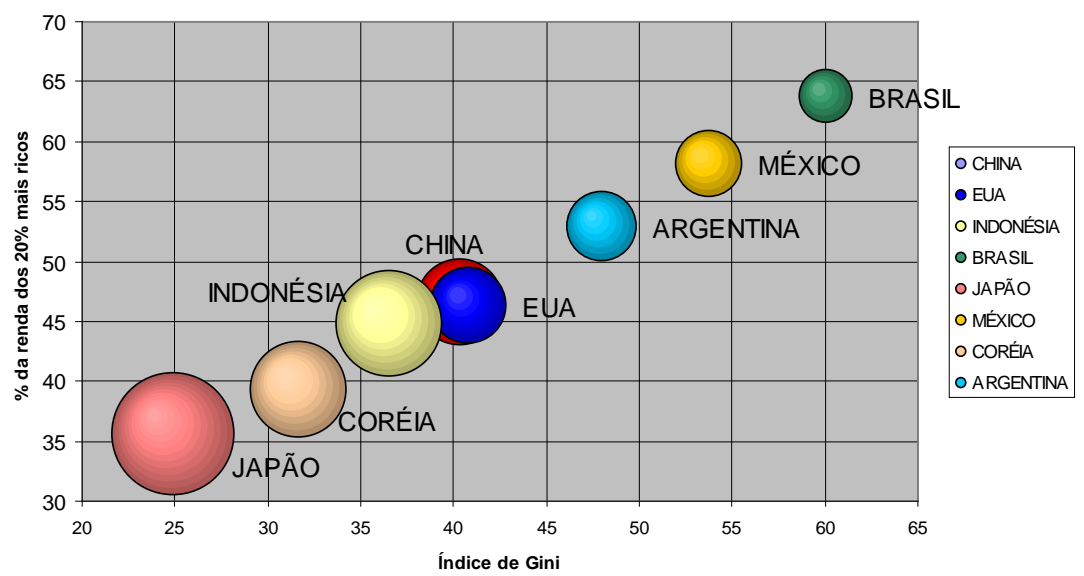

Gráfico 5 - Desigualdade nos anos 1990

Índice de Gini, $20 \%$ mais ricos e $10 \%$ mais pobres (tamanho da bolha)

FONTE: Banco Mundial, 2000; BID, 1998

\section{Conclusão}

$\mathrm{O}$ conjunto dos fatores aqui arrolados demonstra o sucesso das economias do Leste Asiático e do modo de desenvolvimento japonês-asiático em relação ao modo de desenvolvimento anglo-americano, e em relaçáo ao padrão de desenvolvimento dependente latino-americano. Estas conquistas são certamente conquistas políticas, na medida em que representam decisóes e opçóes tomadas ao longo do processo de desenvolvimento de maneira suficientemente coerente, constituindo-se em uma reformulação das relações e estruturas da dependência de maneira a favorecer as condiçóes e necessidades das sociedades do Leste Asiático. Assim, um conjunto de reformas radicais, feitas num momento crucial da história destas naçóes, esteve acompanhado e 
monitorado ao longo do tempo por políticas implementadas por instituiçóes organizativas da sociedade e da economia, que revelam uma boa dose de vontade política bem aproveitada em relação aos objetivos do desenvolvimento sócio-econômico coletivo, ou seja, do modelo de crescimento com igualdade.

Mais ainda, apesar de enfrentarem os mesmos constrangimentos da economia internacional e do capitalismo globalizado, Japão, China e Coréia registram aspectos sócio-econômicos que revelam acertos não somente de políticas econômicas e de políticas públicas (modelos de crescimento nacionais), mas de um padrão de acumulação e de inserção internacional que evidencia dinâmicas e sinergias econômicas mais adequadas e capazes de progredir e beneficiar as sociedades em questão. Ou seja, o modo de desenvolvimento japonês-asiático aparece de maneira generalizada como mais igualitário e mais pujante que os eventuais e pontuais acertos existentes no padráo de desenvolvimento dependente das economias latino-americanas. Comparado com o desenvolvimento dos Estados Unidos, ainda assim ele se apresenta mais igualitário. Dito de outra forma, o capitalismo desenvolvimentista de Estado do Leste Asiático revela uma estrutura de poder e uma configuração de classes sociais dominantes que, com suficiente vontade politica, direcionou as economias destas naçōes de modo a consolidar melhorias nas condiçóes de vida daquelas sociedades. O socialismo de mercado chinês apresenta um processo sócio-econômico com resultados semelhantes.

Concluindo, podemos dizer que, de um modo geral, os indicadores econômicos favorecem a análise positiva do desenvolvimento do Leste Asiático e o seu sistema de oportunidades sociais e econômicas. Estas condições evidenciam que aquela região econômica é socialmente mais igualitária do que a regiāo contida dentro do modo de desenvolvimento anglo-americano. Em outras palavras, é possível compreender o regime de acumulação $e$ o padrão de inserção das economias do Leste Asiático como um modelo de crescimento com igualdade (com menos desigualdade social) que se constitui em uma alternativa melhor, com relação à justiça social e ao bem estar da população - sempre dentro do modo de produção capitalista -, do que o regime de acumulação dependente latino-americano e até mesmo do modo de desenvolvimento concentrador anglo-americano. 


\section{Referências Bibliográficas}

AKYÜZ, Yilmaz; CHANG, Ha-Joon; KOZUL-WRIGHT, Richard. New perspectives on east asian development. Journal of Development Studies, v. 35, n. 6, p. 4-36, ago. 1999.

AKYÜZ, Yilmaz. Debate sobre a arquitetura financeira internacional. Política Externa, v. 9, n. 4, mar./abr./mai. 2001.

. Estate Asian development: new perspectives. Journal of Development Studies, 1998.

ALTIMIR, Oscar. Distribución del ingreso e incidencia de la pobreza a lo largo del ajuste. Revista de La CEPAL, abr. 1994.

ANTUNES, Ricardo. Os sentidos do trabalho. São Paulo: Boitempo, 1999.

BANCO MUNDIAL. China's economic reform in the 1990s. Washington: Banco Mundial, 1997.

. Relatório sobre o desenvolvimento mundial 1995. O trabalhador e o processo de integração mundial. Washington: Banco Mundial, 1995.

. World development report 2000/2001. Washington: Banco Mundial, 2001.

- World development indicators on CD-ROM. Washington: Banco Mundial, 1997, 2000, 2002. 1990 .

BID. Facing Up To Inequality in Latin America. Washington: BID, 1998.

BULMER-THOMAS, Victor (Org.). El nuevo modelo económico en América Latina: su efecto en la distribución del ingreso y en la pobreza. México: Fondo de Cultura Económica, 1996.

CARDOSO, Fernando Henrique; FALETTO, Enzo. Dependencia y desarrollo en América Latina. México: Siglo XXI, 1969.

CASANOVA, Pablo González. Exploração, colonialismo e luta pela democracia na América Latina. Petrópolis: Vozes, 2002. 
CEPAL. América Latina e Caribe: políticas para melhorar a inserção na economia mundial. In: BIELSCHOWSKY, Ricardo. Cinqüenta anos de pensamento na CEPAL. São Paulo: Record-CEPAL, 2000.

. Equidad y transformación productiva. Un enfoque integrado. Santiago: ONU, CEPAL, 1992.

. Estudio económico de América Latina y del Caribe 1996-1997. Sintesis, Santiago, CEPAL, 1997.

- La brecha de la equidad. América Latina, el Caribe y la cumbre social. Resumen y conclusiones. Mimeo, 1997.

. Panorama social de América Latina. Santiago: CEPAL, 1998, 2000, 2001, 2004.

. Pobreza en América Latina: dimensiones y políticas. Santiago: CEPAL, 1985.

- Transformación productiva con equidad. Santiago: ONU/CEPAL, 1990.

CHEN, Shahoua; WANG, Yan. China's growth and poverty reduction: recent trends between 1990 and 1999. Washington: Banco Mundial, jul. 2001.

CHESNAIS, François. A emergência de um regime de acumulação financeira. Praga-Estudos Marxistas, n. 3, 1997.

. A fisionomia das crises no capitalismo mundializado. Novos Estudos Cebrap, n. 52, nov. 1998.

. A mundialização do capital. São Paulo: Xamã, 1996.

CORNIA, Giovanni Andrea. Income distribution, poverty and welfare in transitional economies: a comparison between eastern Europe and China. Journal of International Development, v. 6, n. 5, p. 569-607, 1994.

COUTINHO, Luciano. Coréia do Sul e Brasil: paralelos, sucessos e desastres. In: FIORI, Luis José (Org.). Estados e moedas no desenvolvimento das naçôes. Petrópolis: Vozes, 1999. 
ESTENSSORO, Luis. Capitalismo, desigualdade e pobreza na América Latina. São Paulo, 2003. Tese (Doutorado em Sociologia) - Departamento de Sociologia da Faculdade de Filosofia, Letras e Ciências Humanas/USP, 2003.

EVANS, Peter. O Estado como problema e solução. Lua Nova, n. 28/29, p. 107-156, 1993.

- Transferable lessons? Re-examining the institutional prerequisites of east Asian economic policies. Journal of Development Studies, v. 35, n. 6, p. 66-86, ago. 1999.

FALETTO, Enzo. Problemas de la transformación social en América Latina. In: KLIKSBERG, Bernardo (Org.). ¿Cómo enfrentar la pobreza? Aportes para la acción. Buenos Aires: GEL, 1992.

FERNANDES, Florestan. Capitalismo dependente e classes sociais na América Latina. Rio de Janeiro: Zahar, 1973.

FMI. Japan: economic and policy development. Washington: FMI, IMF Staff Country Report, n. 00/143, nov. 2000.

FURTADO, Celso. Transformaçâo e crise na economia mundial. Rio de Janeiro: Paz e Terra, 1987.

. Globalização das estruturas econômicas. Politica Externa, v. 1, n. 4, mar-abr-mai. 1993.

GONÇALVES, Reinaldo. Globalização e desnacionalização. São Paulo: Paz e Terra, 1999, p. 24-25.

GRAY, John. Falso amanhecer. Os equívocos do capitalismo. Rio de Janeiro: Record, 1999.

GUNDER-FRANK, André. Lumpem-Burguesia: lumpem-desenvolvimento. Porto: Portucalense, 1971.

HIRANO, Sedi; ESTENSSORO, Luis. A América Latina e os países asiáticos: um paralelo sobre os modos de desenvolvimento capitalista. In: DOS SANTOS, Theotônio (Coord.). Globalizaçâo: dimensôes e alternativas. Rio de Janeiro: PUC-Rio, v. II, p. 196-242, 2004 (Série Hegemonia e ContraHegemonia). 
HIRANO, Sedi. A América Latina dentro da hierarquização do mercado mundial. In: SOLAR V. América Latina e Caribe e os desafios da nova ordem mundial. São Paulo: PROLAM-USP, 1998, p. 139-150.

HOBSBAWM, Eric. A era dos extremos. O breve século XX. São Paulo: Companhia das Letras, 1995, p. 285.

HU, Zulia; KHAN, Mohsin. Why is China growing so fast? Washington: FMI, 1997, p. 01-10.

HUNTINGTON, Samuel Phillips. Choque de civilizaçóes e a reconstrução da ordem mundial. Rio de Janeiro: Objetiva, 1997.

IANNI, Octavio. A era do globalismo. Rio de Janeiro: Civilização Brasileira, 1998. . Estado e capitalismo. São Paulo: Brasiliense, 1988. . Sociedade global. Rio de Janeiro: Civilização Brasileira, 1999. . Teoria da globalização. Rio de Janeiro: Civilização Brasileira, 1999.

JAGUARIBE, Helio; HUNTINGTON, Samuel; NOGUEIRA BATISTA Fo, Paulo; BRZEZINSKI, Zbigniew. A nova ordem mundial. Politica Externa v. 1, jun. 1992.

JAPAN ALMANAC. Japão, Asahi Shimbum, de 1995 a 2001.

JOHNSON, Chalmers. Japan: who governs? The rise of the developmental state. New York: Norton, 1995. . MITI and the japanese miracle. Stanford University, 1992.

JOHNSTONE, Christopher. Strained alliance: US-Japan diplomacy in the asian financial crisis. Survival, v. 41, n. 2, 1999.

KHAN, Azizur Rahman. Poverty in China in the period of globalization. New evidence on trend and pattern. Genebra: Discussion Paper 22, OIT, 1998.

KORZENIEWICZ, Roberto Patricio; MORAN, Timothy Patrick. Worldeconomic trends in the distribution of income, 1965-1992. American Journal of Sociology, v. 102 n. 4, p. 1000-1039, jan. 1997. 
KOWARICK, Lúcio. Capitalismo e marginalidade na América Latina. Rio de Janeiro: Paz e Terra, 1985.

KRUGMAN, Paul. America the boastfull. Foreign Affairs, v. 77, n. 3, mai-jun. 1998.

LEW, Roland. En Chine, un etat autoritaire mais faible. Le Monde Diplomatique, p. 18-19, out. 1999.

LIMOEIRO-CARDOSO, Miriam. Capitalismo dependente, autocracia burguesa e revoluçáo social em Florestan Fernandes. São Paulo: IEA/USP, jul. 1997 (Coleção Documentos).

LINCOLN, Edward. Japan's financial mess. Foregn Affairs, v. 77, n. 3, mai-jun. 1998.

LONDOÑO, Juan Luis; SZÉKELY, Miguel. Persistent poverty and excess inequality Latin America, 1970-1995. Washington: BID, 1997.

MACHADO, Vera Barroin. China: desafios e a crise asiática. Novos Estudos CEBRAP, n. 52, nov. 1998.

MARINI, Ruy Mauro. América Latina: dependência e integração. São Paulo: Página Aberta, 1992.

. Dialética da dependência. Petrópolis: Vozes, 2000.

MATTOSO, Jorge. O Brasil desempregado. São Paulo: Fundação Perseu Abramo, 1999.

MEDEIROS, Carlos Aguiar de. Economia e política do desenvolvimento recente na China. Revista de Economia e Política, v. 19, n. 3 (75), p. 96, jul-set. 1999.

. China: entre o Século XX e XXI. In: FIORI, Luis José (Org.). Estados e moedas no desenvolvimento das naçôes. Petrópolis: Vozes, 1999.

MORRIS-SUZUKI, Tessa. The technological transformation of Japan. Cambridge: Cambridge University Press, 1994.

NAKAMURA, Takafusa, The postwar japanese economy - it's development an structure, 1937-1944. Tokio: University of Tokio Press, 1994. 
OCDE. Economic survey of Japan. OCDE Observer, 2000. . Economic Outlook 76 Database. OCDE.

OLIVEIRA, Amaury Porto. Capitalismo sul-coreano. Politica Externa, v. 9, n. 3, dez./jan./fev. 2000, 2001.

PNUD. Uma estratégia para a superação da pobreza na América Latina. Estudos Avançados, São Paulo, v. 6, n. 16, p. 157-182, set-dez. 1992.

. Human Development Report 1992. Nova York, Oxford University Press, 1992.

. Relatório de desenvolvimento humano 1996. Lisboa: Tricontinental, 1996.

. Relatório de desenvolvimento humano 1997. Lisboa: Trinova, 1997.

QUIJANO, Aníbal. La economía popular y sus caminos en América Latina. Lima, Mosca Azul, 1998.

REYNA, José Luis (Org.). América Latina a fines del siglo. México: Fondo de Cultura Económica, 1994.

ROUQUIÉ, Alain. O extremo-ocidente. Introdução à América Latina. São Paulo: EDUSP, 1991.

SAKAIYA, Taichi. Japão: as duas faces do gigante. Lisboa: Difusão Cultural, 1994.

SALAMA, Pierre; VALIER, Jacques. Pobrezas e desigualdades no $3^{\circ}$ mundo. São Paulo: Nobel, 1997.

SALAMA, Pierre. Pobreza e exploração do trabalho na América Latina. São Paulo: Boitempo, 1999.

SCHILLING, Voltaire. EUA X América Latina. As etapas da dominação. Porto Alegre: Mercado Aberto, 1984.

SEN, Amartya. Valeurs asiatiques et croissance économique. Le Monde, 27 de outubro de 1998.

. Desenvolvimento como liberdade. São Paulo: Cia. das Letras, 2000. 
SHICHENG, Xu. Sobre la reforma en China. São Paulo: Depto. de Ciência Política da FFLCH/USP, Série Política Internacional 10, 1992.

STALLINGS, Bárbara; SZÉKELY, Gabriel. Japan, the United States and Latin America. Baltimore: John Hopkins University Press, 1993.

SUNKEL, Osvaldo. Las relaciones centro-periferia y la transnacionalización. Pensamiento Iberoamericano, n. 11, p. 31-57, jan-jun. 1987.

TAVARES, Maria da Conceição. Império, território e dinheiro. In: FIORI, Luis José (Org.). Estados e moedas no desenvolvimento das naçóes. Petrópolis: Vozes, 1999.

THUROW, Lester. Head to head: the coming economic battle between Japan and America. Nova York: William Morrow, 1992.

TOMASSINI, Luciano (Org.). Transnacionalización y desarrollo nacional en América Latina. Buenos Aires: GEL, 1984.

TOURAINE, Alain. Palavra e sangue - politica e sociedade na América Latina. São Paulo: Trajetória Editorial, 1989.

TRAGTENBERG, Maurício. Burocracia e ideologia. São Paulo: Ática, 1992.

TSURU, Shigeto. Japan's capitalism - creative defeat and beyond. Cambridge: Cambridge University Press, 1994.

VADNEY, Thomas E. The world since 1945. London: Penguin Books, 1992.

WEINBERG, Daniel; JONES Jr., Arthur. The changing shape of the nation's income distribution. US Census Bureau, Current Population Reports, jun. 2000 .

WEINBERG, Daniel. A brief look at postwar US income inequality. US Census Bureau, Current Population Reports, jun. 1996.

YAO, Shujie. Economic development and poverty reduction in China over 20 years of reforms. Economic Development and Cultural Change, v. 48, n. 3, p. 447-474, 2000.

. Economic growth, income inequality and poverty in China under economic reforms. Journal of Development Studies, v. 35, n. 6, p. 104-130, ago. 1999. 
YOU, Jong-Il. Income distribution and groth in East Asia. Journal of Development Studies, v. 35, n. 6, p. 37-65, ago. 1999.

ZHANG, Amei. Poverty alleviation in China: commitment, policies and expenditures. Mimeo, 1993. 